\title{
A comparative study of the roots of Ranunculacex.
}

\author{
FRED B. MAXWELL.
}

WITH PLATES II-IV.

\section{Historical Introduction.}

After the beginning of the present century, when plant anatomy began seriously to attract the attention of botanists, the cell wall was the first subject of investigation; then the actively growing parts above ground; and finally the roots of plants were studied. Nevertheless the latter have received far less attention proportionally than the other organs of plants.

In reviewing the history of the microscopic investigation of roots the development of the subject appears in two distinct Feriods. ${ }^{1}$ Previous to 1865 anatomists such as Mirbel, von Mohl, and Trecul, studied the various masses of tissues making up roots, and the cells composing them. Since r865 study has been more directed to the origin of organs and the various parts of organs. Among the more important writers of this period are Nägeli, Hanstein, Reinke, Janczewski, Treub, Erickson and Flahault.

The first period dealt with the histological elements in and for themselves, the second went farther and sought their origin and development; the first mainly investigated mature organs, the second took up the study of the young and newly formed parts, the meristem, especially in their relation to the formation of the mature parts.

In I810 Mirbel, ${ }^{2}$ the earliest of the important writers of the first period, studied the roots of Nymphaea lutea, and in I 83 I Hugo von Mohl, ${ }^{3}$ from the study of the roots of a palm, made the distinction between the central cylinder, cortex, and epidermis. Trecul, ${ }^{4}$ among other histological articles published one in 1846 concerning the origin of roots. Although in time belonging to the second period, I will
refer here to a series of articles by Van Tieghem, since these

\footnotetext{
${ }^{1}$ For the résumé of the works of the earlier writers I am indebted to the admirable articles by Flahault, Janczewski and Olivier.

'Examen de la division des vegetaux en endorhizes et exorhizes. Comptes rendus, Oct. 8, i8 io. Ann. du Museum, xvi.

${ }^{3} \mathrm{De}$ Palmarum structuro.

${ }^{4}$ Recherches sur l'origine des racines.
}

Ann. des Sci. Nat. III. v. 340 . 
articles dealt more with general plant anatomy than with meristematic structure, the first article $^{5}$ dealing particularly with root structure. After stating that certain arrangements of tissues are only found in certain organs, he takes up each organ and studies the modifications of the fundamental structure for that organ, as found in the various classes, orders, genera, etc., of plants. He points out the distinction between root and stem structure, as based on the arrangement of the fibro-vascular bundles, the former normally having radial bundles, the latter collateral ones, though older roots of dicotyledons take on an arrangement similar to the stem structure. He was not the first, however, to call attention to the change taking place in the roots of dicotyledons, since Nägeli as early as $1858^{6}$ had shown that the older roots of many dicotyledons possessed a different structure from the younger roots of the same plant, and that the condition of the younger roots of dicotyledons was the permanent condition of the roots of monocotyledons.

The first important generalization concerning meristem structure to receive immediate consideration of other workers was made by Nägeli and Leitgeb. ${ }^{7}$ They found that in vascular cryptogams the several zones of tissues of both stem and root were derived from a single apical cell situated in the vegetative point. All vascular cryptogams studied showed this structure, and they assumed that phanerogams would present a similar development at the growing point, and in young roots they asserted that all the tissues could be traced to a single apical cell as their origin, but in older roots later growth concealed this primary structure. Before this time Otto Nicolai ${ }^{8}$ had said that the vegetative point in phanerogams was a group of cells, which, by means of successive division, formed on one side the root cap and on the other the body of the root.

In 1868 Hanstein $^{9}$ declared that in phanerogams, the initial at the vegetative-point is never of a single cell, but of a

\footnotetext{
${ }^{5}$ Ann. des Sci. Nat. V. xirr.

${ }^{6}$ Sur l'accroissement de la tige et de la racine dans les plantes vasculaires. Beitræge zur wissensch. Bot. 1858 .

${ }^{7}$ Entstehung und Wachsthum der Wurzeln. Beitræge zur wissensch. Botan. 4. 138 .

${ }^{8}$ Das Wachsthum der Wurzel, 1865.

${ }^{9}$ Die Scheitelzellgruppe im Vegetationspunkt der Phanerogamen. Bonn. 1868 .
} 
group of cells, and added that the root-cap was from sister cells separated from the epidermis. To the meristematic epidermis he gave the name of dermatogen. In $1870^{10}$ he confirmed this first assumption in a paper, the conclusions of which were quite generally accepted at the time. According to him the cortex and central cylinder each has an initial group of its own, and the root-cap is derived from the epidermis, one being able to trace it for a certain distance under the root-cap. He completely exploded Nägeli's theory of a single apical cell for phanerogams, but he fell into an error similar to Nägeli's in supposing that all phanerogams followed the type explained above. Hanstein was followed by a pupil of his, Reinke ${ }^{11}$, who, by the study of mature roots, confirmed Hanstein's conclusions, Hanstein's studies having been made on the roots of embryos. Although Reinke examined but few roots, and all of those of angiosperms, he held that all phanerogams had the structure of the one species especially examined, that is Helianthus annuus. Reinke admitted some variations from type, but held that these were not of enough importance to found a new type.

Prantl ${ }^{12}$ opposed Reinke's general statement, saying that in maize the epidermis was distinct from the root-cap, possessing an initial group of its own, and in Pisum and Vicia he found that the primitive tissues were confluent at the vegetative-point. In a short note ${ }^{13}$ Reinke had already admitted that in Pinus pinea the root-cap was not from the dermatogen, but from the periblem, or perhaps that the rootcap was absent and that the cortex served its purpose, being thrown off and developing again.

About the same time Strasburger ${ }^{14}$ published a memoir in which he held that all Coniferce, Gnetacee and Cycadece have the structure made out for Pinus pinea. Reinke admitted that this was probably true. The appearance of doubtful cases has made uncertain the acceptance of Hanstein and Reinke's theory of one type of meristem structure for the roots of all

\footnotetext{
${ }^{10}$ Die Entwicklung des Keimes der Monocotylen und Dicotylen. Botan.

Abhandl. aus d. Gebiete der Morphologie und Physiologie. I. Bonn. 1870.

${ }^{11}$ Untersuchungen über Wachsthumgeschichte und Morphologie der Phanerogamenwurzel. Botan. Abhandl., etc., III, I87I. $1{ }^{2}$ Regeneration der Vegetationspunktes an Angiospermenwurzeln. Arb. des
Bot. Instituts Würzb. 4, 1874 .

${ }^{13}$ Bot. Zeit. 1872 .
}

${ }^{14}$ Die Coniferen und Gnetaceen. Jena 1872 . 
phanerogams and it only needed Russow's ${ }^{15}$ article to prove that this type was not a universal one. Mainly through the study of embryos he compared the roots of phanerogams with those of vascular cryptogams. He found that the roots of all phanerogams did not follow the Helianthus type, for in the embryos of several Leguminosa and in many older roots of dicotyledons one could not trace the epidermis under the rootcap, on the contrary the dermatogen entered the primary meristem of a continuous layer; and he found that in many roots there was no distinction between the dermatogen and the periblem, or between the dermatogen and calyptogen, and sometimes the periblem and plerome were not distinctly separated.

In 1874 appeared Janczewski's ${ }^{16}$ very important memoir. $\mathrm{He}$ reviewed the work that had preceded his, especially criticising Reinke, asserting that he endeavored to prove a preconceived conclusion, and that his investigations were not sufficiently accurate and extended to base important deductions upon. In making his investigations Janczewski studied the roots of embryos, developing roots, and mature roots, the best results being obtained from the study of the latter, and he bases his conclusions upon this study. He proposed five principal types of meristem structure at the growing-point in the roots of phanerogams. His five types are as follows:

First type, roots having four independent primary tissues at the vegetative point, and so four initial groups, a calyptrogen, a dermatogen, a periblem and a plerome. He placed but two plants in this type, Hydrocharis and Pistia. .

Second type, roots having three independent primary tissues, a sharply defined calyptrogen and plerome, and between these an initial group from which arise the cortex and epidermis, or perhaps no true epidermis present, the outer layers of the cortex taking its place. This is the type to which he assigns most of the monocotyledons.

Third type, roots with three primary tissues, the plerome and periblem being sharply defined but the epidermis and root-cap having a common origin. Here he would include most dicotyledons.

${ }^{15}$ Vergleichende Untersuchungen, etc., der Phanerogamen, ausgehend von der Betrachtung der Marsiliaceen. Mém. Acad. de St. Petersburg, VII. xix (1872).

${ }^{16}$ Das Spitzenwachsthum der Phanerogamenwurzeln. Bot. Zeit. 1874. Sci. V. $x x$.

Recherches sur le developpement des radicelles dans les Phan. Ann. des 
Fourth type, root with but one primary tissue at the vegetative point, the initial groups of all tissues being confluent, or perhaps we should say possessing a common initial group for all the tissues. Example, some Cucurbitacee and Papilionacea.

Fifth type, roots with two primary tissues, the plerome and periblem being distinct, and the outer layers of the cortex serving the purpose of an epidermis and root-cap. To this type belong the gymnosperms.

It will be seen that the first four types pertain to angiosperms and the last to gymnosperms, while the first two includes monocotyledons, and the third and fourth dicotyledons. Hanstein and Reinke's general type is Janczewski's third type, while the fifth type confirms Reinke and Strasburger's work on gymnosperms.

Hegelmaier ${ }^{17}$ from the study of embryo roots, would add at least two other monocotyledons to Janczewski's first type. He says that at a very early stage the root-cap is formed by tangential division from the dermatogen, and later growth is by centripetal division of this layer and not from the dermatogen.

In 1876 two important articles upon meristem structure appeared. Treub, from a study of the roots of monocotyledons, ${ }^{18}$ would make three types of terminal meristem structure for them, retaining Janczewski's first type and dividing the second into two others. Erickson, ${ }^{19}$ from a similar study of dicotyledons would make four types of meristem structure for them. His types are as follows:

First type, roots having three well marked meristem tissues at the vegetative point, a plerome, a periblem, and combined dermo-calyptrogen layer, from which both the epidermis and root-cap arise. This is Janczewski's third type.

Second type, but two well marked meristem tissues in the root, a distinct plerome and a common initial for the cortex, epidermis and root-cap. In this type Erickson places several Malvacea and scattered species from other groups.

Third type, a common origin for all the tissues, the initial of all the groups coalescing. This is Janczewski's fourth type.

\footnotetext{
${ }^{17}$ Zur Entwicklung monocotyl. Keime, etc. Bot. Zeit. 1874 .

${ }^{18} \mathrm{Le}$ meristeme primit. de la racine dans les monocot. Leyden, 1876.

${ }^{19}$ Ueber das Urmeristem der Dicotylenwurzeln. Jahrbücher für wissensch. Botan. Leipzig, I877.
} 
Here Erickson includes most of the Leguminosa and a few species from several other groups, including all of the Ranunculacee which he examined, though saying that these differed from the type in that the periblem developed centrifugally instead of centripetally.

Fourth type, roots having but two well marked meristem tissues, a plerome and a periblem, the outer layers of the cortex answering to the epidermis and root-cap. This agrees with Janczewski's fifth type which he made for gymnosperms.

In an article published in $1878^{20}$ Flahault discusses the theories of structure of the root at its vegetative tip. $\mathrm{He}$ thinks that it was on account of Hanstein and Reinke not understanding the early separation of the calyptrogen from the dermatogen that they placed monocotyledons in the Helianthus type. After making a study of the roots of three hundred and fifty species, representing nearly all of the natural orders of plants, he makes two types of primary meristem for angiosperms, one for dicotyledons and one for monocotyledons, distinguishing the two types by the latter always having a distinct calyptrogen layer. The other types as made out by Janczewski and others he would regard as but forms of these two, for between them are all manner of gradations, while the two main types are very distinct.

Fleischer ${ }^{21}$ found that in a Funcus and Luzula the root-cap had an origin of its own while other plants he studied conformed to the Helianthus type. Bruchman claimed to have made out four primary meristem tissues in the roots of grasses which he studied, but did not give details of work or results.

Thus we see that later workers agree that Hanstein and Reinke's assumption of one type of meristem structure for all phanerogams was untenable. As to how many types there are opinions differ widely.

M. Halle ${ }^{22}$ tried to reduce Janczewski's two types for dicotyledons to one type, and adds a number of species as belonging to the Helianthus type. He considered Janczewski's fourth type the result of degeneration through excessive development at the vegetative point. He made careful studies of the embryos of many Leguminose, said to belong to this

${ }^{20}$ Recherches sur l'accroissement terminal de la racine chez les phanerogams. Ann. des Sci. Nat. VI. vi.

${ }^{21}$ Beitræge zur Embryogenie der Monokotylen und Dikotylen. Flora, 1874.

22 Bot. Zeit. 1876 and 1877 . 
fourth type, and found that in this stage they followed the Helianthus type and only later were the initial groups merged into one. Hence he would not consider this as a distinct type. He also points out divergencies from type structure in the roots of other plants, and considers Janczewski's first type but a variation of the second, since he thinks in the roots of Vallisneria spiralis he found an intermediate form between the two types. He agrees with Russow that the root must be studied in all stages of development before we can arrive at safe conclusions.

Flahault says of Halle's paper that it furnished important conclusions, but that the number of species studied were too few and the reasons given were not sufficient to put a stop to all discussion, and after his own more extended studies he arrives at about the same conclusion and would make but two general types of meristem structure for the roots of angiosperms.

In 1877 De Bary ${ }^{23}$ made a résumé of the work accomplished on the meristem of roots. After discussing the work of various authors he asks, "If the organization of the different systems of tissues, and the structure of the organs ought to be considered as connected with the organization of the terminal meristem, and also if each tissue always takes its birth in the same part of the primary meristem." After reviewing the principal modifications of the structure of the vegetative point of the root, he says, "Determined zones of meristem are not always to be considered as the origin of determined tissues, although it might be so in many cases."

While the résumé which we have made shows us that much has been done in investigating the structure of the vegetative point of roots, it also shows us that there is much confusion as to the types of structure which should be recognized, which confusion can only be cleared up by a careful study of the roots of all the natural orders of plants.

I have undertaken to make a study of the roots of the native Ranunculacea, especially as to the meristem of the vegetative point, but also somewhat as to the general histological structure of the root. The results of this study will be found in parts II and III of this paper, but before taking up that study the following résumé of work already done on the roots of this order may be found useful.

${ }^{23}$ Vergleich. Anat. der Vegetationsorgane, etc. 
Having had access only to reviews of many of the earlier articles referred to in this paper, I cannot say whether some of them may not have worked upon this group, but the titles of their papers would indicate that many of them had not done so. Of the more important articles which I reviewed I find that neither Van Tieghem nor Janczewski appears to have included any of the Ranunculacee in their studies. Erickson, as already referred to, studied the roots of several of the Ranunculacea, among them being Ranunculus repens, of which he gives a figure of the meristem, and Caltha palustris. Flahault, in his article published in 1878 , refers to the structure of the roots of several of this order, and he agrees with Erickson that the tissues merge into one at the vegetative point, but would say that this was but a modification of the general type for dicotyledons. He figured the root tip of Peonia officinalis and Aconitum pyrenaicum. Hegelmaier, in an article on the growth of the embryo in dicotyledons, treats at length of several Ranunculacea, but gives slight reference to the root structure, and does not dwell on the meristem of the growing-point. Olivier ${ }^{24}$ treats mainly of the histological structure of roots and places Ranunculacee in a class of plants in which the secondary vascular tissue appears very late, adding that in the roots of the genus Ranunculus there is less secondary vascular development than in any other dicotyledon. He says of the genus Thalictrum that the secondary growth appears late, and but very little developed, that the cortical parenchyma is often nearly all exfoliated, the endodermis being persistent and then serving the purpose of an epidermis. De Bary discusses the root structure of several of the Ranunculacea, and gives figures of the cross-section of the root of Ranuniulus fluitans and $R$. repens. P. Marie ${ }^{25}$ gives an important article on the histological structure of Ranunculacea, referring to the general histological structure of the roots as well as to that of the stem, etc., but he does not refer to the meristem structure. He gives many good figures of root structure.

Prof. Hargitt ${ }^{26}$ published a short article in the Botanical GAZETTE, in which he describes the structure of the roots of Isopyrum biternatum. VI. II.

${ }^{24}$ Recherches sur l'appareil tegumentaire des racines. Ann. des Sci. Nat.

${ }^{25}$ Recherches sur la structure des Ranonculacees. Ann. des Sci. Nat. VI. xx.

${ }^{26}$ Botan. Gazette xv (1890). 235. 
Thus we see that work upon the roots of this order, especially as to the meristem, has been very limited. In the parts of this paper which follow I have endeavored to point out certain types of structure, as I have found them in the roots of the native species of Ranunculacee.

University of Chicago.

\section{Method for obtaining pure cultures of Pammel's fungus of Texas root rot of cotton. ${ }^{1}$}

\section{GEO. F. ATKINSON.}

It is not a very difficult matter to obtain artificial pure cultures of spore producing fungi which grow readily in artificial nutrient media. But when we meet with forms of fungi, the spore production of which is unknown, quite a serious difficulty is encountered since spores of other fungi, as well as numerous bacteria, are so apt to be securely lodged in the strands of the mycelium. This serious difficulty is increased when the fungus in question shows a decided aversion to growing on the usual artificial media. The fungus of Texas root rot of cotton, described by Pammel in Bulletin no. 7 of the Texas Agricultural Experiment Station, has not yielded to the methods usually resorted to in obtaining pure cultures.

After trying various methods Pammel failed to obtain a pure culture. In one case threads of the fungus were swept with a camel's hair brush with the hope of obtaining spores. A "pure culture of some fungus" was obtained but its morphological characters were unlike those of the fungus found on the roots of cotton.

During the summer of I891, at Auburn, Ala., I made several attempts from fresh material received from Texas to induce the fungus to part its hold on the cotton roots and grow under my care and observation. All attempts at that time failed. Affected roots were placed on sand in moist chambers and the fungus strands grew in several cases from four to six inches out over the surface of the sand. When portions of these strands were transferred to nutrient media they failed to grow. ${ }^{1}$ Paper presented before the Botanical Section of the Am. Assoc. Agr. Coll.
and Exp. Sta. New Orleans, Nov. 16, 1892. 


\section{$2 \mathrm{BHL}$ Biodiversity Heritage Library}

Maxwell, Fred B . 1893. "A Comparative Study of the Roots of Ranunculaceæ." Botanical gazette 18(1), 8-16. https://doi.org/10.1086/326879.

View This Item Online: https://www.biodiversitylibrary.org/item/93151

DOI: https://doi.org/10.1086/326879

Permalink: https://www.biodiversitylibrary.org/partpdf/222217

\section{Holding Institution}

Missouri Botanical Garden, Peter H. Raven Library

\section{Sponsored by}

Missouri Botanical Garden

\section{Copyright \& Reuse}

Copyright Status: Public domain. The BHL considers that this work is no longer under copyright protection.

This document was created from content at the Biodiversity Heritage Library, the world's largest open access digital library for biodiversity literature and archives. Visit BHL at https://www.biodiversitylibrary.org. 